\title{
The determination of health practices and the sexual quality of life during the prenatal period
}

\author{
Nazife Bakır ${ }^{1}$ (D), Pınar Irmak Vural ${ }^{2}$ (D) , Cuma Demir ${ }^{1}$ \\ ${ }^{1}$ Health School, Burdur Mehmet Akif Ersoy University, Burdur, Turkey \\ ${ }^{2}$ Department of Nursing, Faculty of Health Sciences, Istanbul Medipol University, Istanbul, Turkey
}

\begin{abstract}
Objective: The aim of this study is to determine health practices and sexual quality of life of women during the prenatal period.

Methods: The study was conducted with 312 pregnant women without threatened preterm labor who admitted to the clinic of obstetrics and gynecology in a state hospital in the Mediterranean region between June and September 2019. The data were collected by the Descriptive Features Form, the Health Practices in Pregnancy Questionnaire and the Sexual Quality of Life-Female Questionnaire. Results: It was found in the study that $93.6 \%$ of the pregnant women were married, $69.2 \%$ of them had planned pregnancy and $54.7 \%$ of them underwent prenatal care for more than 4 times. The mean scores of the Health Practices in Pregnancy Questionnaire and the Sexual Quality of Life-Female Questionnaire were 87.55 \pm 5.49 and $63.88 \pm 5.95$, respectively. It was observed that the health practices of the pregnant women who were younger and underwent prenatal care for more than 4 times were better. Also, it was found that the pregnant women in the 2nd and 3rd trimesters had higher scores than those in the 1 st trimester.

Conclusion: The health practice levels of the pregnant women are low while the levels of sexual quality of life are moderate in the study.
\end{abstract}

Keywords: Prenatal period, health practices, sexual life, nurse.

\section{Introduction}

Pregnancy is a period in which women undergo many physiological changes and prioritized care should be provided. A great part of the reasons deteriorating the maternal health is associated the with deviation of peri-
Özet: Prenatal dönemde sağlık uygulamaları ve cinsel yaşam kalitesinin belirlenmesi

Amaç: Bu çalışmanın amacı prenatal dönemdeki kadınların sağlık uygulamaları ve cinsel yaşam kalitesinin belirlenmesidir.

Yöntem: Haziran-Eylül 2019 arasında Akdeniz bölgesindeki bir devlet hastanesinde kadın hastalıkları ve doğum polikliniğine başvuran, erken doğum tehdidi bulunmayan 312 gebe kadınla yürütüldü. Veri toplamada Tanıtıcı Özellikler Formu, Gebelikte Sağlık Uygulamaları Ölçeği ve Cinsel Yaşam Kalitesi Ölçeği-Kadın Formu uygulandi.

Bulgular: Araştırmada gebelerin \%93.6'sının evli olduğu, \%69.2'sinin gebeliğinin planlı olduğu ve \%54.7'sinin 4 defadan fazla doğum öncesi bakım aldığı saptandı. Gebelikte Sağlık Uygulamaları Ölçeği puan ortalaması 87.55 \pm 5.49 , Cinsel Yaşam Kalitesi Ölçeği-Kadın Formu puan ortalaması $63.88 \pm 5.95$ idi. Genç yaşta olan ve 4'ün üzerinde doğum öncesi bakım alan gebelerin să̆lık uygulamalarının daha iyi olduğu görüldü. Ayrıca 2. ve 3. trimesterdeki gebelerin, 1. trimesterdekilere göre daha yüksek puan aldığı saptandi.

Sonuç: Çalışmada gebelerin sağlık uygulamaları düşük, cinsel yaşam kalitesi ise orta düzeydedir.

Anahtar sözcükler: Prenatal dönem, sağlık uygulamaları, cinsel yaşam, hemşire.

Correspondence: Nazife Bakır, MD. Health School, Burdur Mehmet Akif Ersoy University, Burdur, Turkey.

e-mail: nazbakir@hotmail.com / Received: December 13, 2019; Accepted: February 13, 2020

Please cite this article as: Bakır N, Irmak Vural P, Demir C. The determination of health practices and the sexual quality of life during the prenatal period. Perinatal Journal 2020;28(1):1-6. doi:10.2399/prn.20.0281001 
ly changes during pregnancy and prenatal tests and examinations, and they should adopt health practices during prenatal care. Nurses provide training and consultancy to pregnant women and their spouses and help them to have a healthy baby by providing accurate and complete information to couples about the health practices that may affect pregnancy and labor ${ }^{[1]}$ Prenatal health practices can be defined as the activities affecting gestational outcome and involving the health of pregnant woman, fetus and newborn. These practices include non-smoking, undergoing dental care, balanced diet and proper weight gain, not consuming alcohol and illegal substances, having training about pregnancy and labor, regular exercising, and avoiding risky sexual behaviors or exposure to other infection agents. ${ }^{[3]}$

During prenatal period, sexual desires and sexual intercourse frequency vary depending on the gestational period. Nausea, vomiting, fatigue, sleeping orientation, bodily changes, breast pain, tenderness and frequent urination usually lead to the reduced sex drive in the first trimester. The complaints start to decrease in the second trimester, and pelvic congestion increases. The sexual desires increase in mother who adapts to pregnancy. The growing fetus and physical complaints in the last trimester may cause sex drive to reduce. As the labor date approaches, the fear of having pain during labor, infection fear and the perceptions about experiencing abnormal conditions during sexual intercourse may have an impact on the sexual life of the couples. ${ }^{[1]}$ The reasons such as the sex perception of the couples, cultural norms, lack of information, the idea of parenthood, negative thoughts about sex and the thought that baby may get hurt can have a negative impact on the sexual life during pregnancy. ${ }^{[4]}$ Unlike the myths, fetus does not suffer from the sexual intercourse if the hygienic conditions are good and there are no conditions such as placenta previa or premature rupture of membranes. Mucoid plaque which provides protection against infections and amniotic sac which acts like an air bag prevents fetal trauma. In addition, the increased blood flow during sexual intercourse and elevation in the hormones during and after the orgasm affect fetal health positively. ${ }^{[5,6]}$ Nurses should inform couples during the prenatal follow-ups on their concerns about sex and encourage them to discuss it. They should encourage women to share their concerns with their spouses by initiating a safe communication, and tell them that sexual inter- course is not harmful for fetus. It should be explained to the couples that sexuality is not limited with the sexual intercourse, but they may also express their intimacy to each other by caressing, hugging, and kissing. ${ }^{[1]}$

This study was planned to determine the health practices and sexual quality of life of women during prenatal period.

\section{Methods}

\section{The study type}

This is a descriptive and cross-sectional study.

\section{Study population and sample}

The study population comprised of all pregnant women without threatened preterm labor who admitted to the outpatient clinic of obstetrics and gynecology in a state hospital in the Mediterranean region. The study sample comprised of 312 pregnant women without threatened preterm labor who admitted to the outpatient clinic of obstetrics and gynecology between June and September 2019 and accepted to participate in the study. The pregnant women who accepted to participate in the study were included in the research by the improbable randomized sampling method.

\section{Data collection}

In order to collect the data of the pregnant women, the descriptive features form, "The Health Practices in Pregnancy Questionnaire" and "The Sexual Quality of Life-Female Questionnaire" were used. The pregnant women who were literate and had no problem with Turkish language were included in the study while the pregnant women with the threatened preterm labor were excluded.

\section{Descriptive Features Form}

The form created by the researchers includes 15 questions collecting the socio-demographic and obstetric characteristics of the pregnant women.

\section{The Health Practices in Pregnancy Questionnaire (HPPQ)}

It was developed by $\operatorname{Lindgren}^{[3]}$ in 2005, and its Turkish validity and reliability analysis was done by $\mathrm{Er}^{[7]}$ in 2006. Turkish validity and reliability form of the questionnaire has 33 items. The items between 1 and 16 comprise of responses in the 5 -point Likert 
type varying between "never, rarely, occasionally, frequently, always". For the questions between items 17 and 33, appropriate answers scored between 1 and 5 were provided. The total score is calculated by the sum of all items. The score range of the questionnaire is 33-165. Higher scores indicate that health practices are good. Cronbach's alpha coefficient was found 0.74 in the validity analysis of the questionnaire. ${ }^{[7]}$ In our study, Cronbach's alpha coefficient was 0.71 .

\section{The Sexual Quality of Life-Female Questionnaire (SQOL-F)}

It was developed by Symonds et al. ${ }^{[8]}$ in 2005 for the evaluation of sexual quality of life. Turkish validity and reliability analysis of the questionnaire was done by Tuğut and Gölbaşı in 2010. It was reported that the reliability coefficient of the total item score of SQOL-F was $\mathrm{r}=0.32-0.67$, and Cronbach's alpha coefficient was 0.83 . Tuğut and Gölbaş1 ${ }^{[9]}$ used a scoring system between 1 and 6 in their study. In this scoring system, the minimum score is 18 and the highest score is 108 . In order to convert the questionnaire score into 100 , the following formula is used: (raw score obtained in the questionnaire $18) \times 100 / 90$. As the score obtained in the questionnaire increases, the sexual quality of life increases as well. In our study, Cronbach's alpha coefficient was 0.77 .

\section{Statistical analysis}

The data of the study were analyzed by SPSS 20.0 (SPSS Inc., Chicago, IL, USA) and percentage, frequency, one-way ANOVA and independent groups t-test were used. The significance level was considered $\mathrm{p}<0.05$.

\section{The ethics aspect of the study}

The ethical approval of the study was obtained from the Non-Invasive Clinical Researches Ethics Committee of İstanbul Medipol University (Ethics Committee approval no. 10840098-604.01.01-E.19312). The study was conducted in accordance with the Declaration of Helsinki, and written and verbal consents of the cases were received.

\section{Results}

In our study, we found that $50.3 \%$ of the cases were between 32 and 38 years old, the educational level of $55.1 \%$ of them were primary school or below, and $52.6 \%$ of them were living in the county. Of the pregnant women, $93.6 \%$ were married, and $56.4 \%$ had a moderate level of income. It was found that $69.2 \%$ of the cases were planned pregnancies, half of the pregnant women were in the 2 nd trimester and $54.7 \%$ of them underwent prenatal care for more than 4 times (Table 1).

The mean scores of HPPQ and SQOL-F are given in the Table 2, which are $87.55 \pm 5.49$ and $63.88 \pm 5.95$, respectively.

Table 1. The distribution of the pregnant women according to the descriptive features.

\begin{tabular}{|c|c|c|c|}
\hline \multicolumn{2}{|c|}{ Descriptive features ( $\mathrm{N}=312)$} & \multirow{2}{*}{$\begin{array}{l}n \\
70\end{array}$} & \multirow{2}{*}{$\begin{array}{c}\% \\
22.4\end{array}$} \\
\hline Age & $18-24$ & & \\
\hline & $25-31$ & 66 & 21.2 \\
\hline & $32-38$ & 157 & 50.3 \\
\hline & 39 and above & 19 & 6.1 \\
\hline \multirow[t]{3}{*}{ Education level } & Primary education and below & 172 & 55.1 \\
\hline & Secondary education & 106 & 34.0 \\
\hline & University and above & 34 & 10.9 \\
\hline \multirow[t]{3}{*}{ Place of residence } & City & 55 & 17.6 \\
\hline & County & 164 & 52.6 \\
\hline & Village & 93 & 29.8 \\
\hline \multirow[t]{2}{*}{ Marital status } & Married & 292 & 93.6 \\
\hline & Single & 20 & 6.4 \\
\hline \multirow[t]{3}{*}{ Income level } & High & 68 & 21.8 \\
\hline & Moderate & 176 & 56.4 \\
\hline & Low & 68 & 21.8 \\
\hline \multirow[t]{2}{*}{ Pregnancy type } & Planned pregnancy & 216 & 69.2 \\
\hline & Unplanned pregnancy & 96 & 30.8 \\
\hline \multirow[t]{3}{*}{ Month of gestation } & $1,2,3$ months & 48 & 15.4 \\
\hline & $4,5,6$ months & 156 & 50.0 \\
\hline & 7, 8,9 months & 108 & 34.6 \\
\hline \multirow[t]{4}{*}{ Number of pregnancy } & 1 & 105 & 33.7 \\
\hline & 2 & 101 & 32.4 \\
\hline & 3 & 82 & 26.3 \\
\hline & 4 and more & 24 & 7.7 \\
\hline \multirow[t]{3}{*}{ Number of children } & None & 105 & 33.7 \\
\hline & $1-2$ & 183 & 58.7 \\
\hline & $3-4$ & 24 & 7.6 \\
\hline \multirow{3}{*}{$\begin{array}{l}\text { Number of } \\
\text { prenatal care }\end{array}$} & Less than 4 times & 84 & 27.0 \\
\hline & 4 times & 57 & 18.3 \\
\hline & More than 4 times & 171 & 54.7 \\
\hline \multirow{2}{*}{$\begin{array}{l}\text { The history of sexually } \\
\text { transmitted disease }\end{array}$} & Yes & 18 & 5.8 \\
\hline & No & 294 & 94.2 \\
\hline
\end{tabular}

Table 2. The mean scores of the Health Practices in Pregnancy Questionnaire (HPPQ) and the Sexual Quality of Life-Female Questionnaire (SQOL-F).

\begin{tabular}{lcccc} 
Questionnaires & Minimum & Maximum & Mean & SD \\
HPPQ & 74.00 & 116.00 & 87.55 & 5.49 \\
SQOL-F & 43.33 & 80.00 & 63.88 & 5.95 \\
\hline
\end{tabular}


Table 3. The comparison of the scores of the Health Practices in Pregnancy Questionnaire and the Sexual Quality of Life-Female Questionnaire according to the descriptive features of the pregnant women.

\begin{tabular}{|c|c|c|c|c|c|}
\hline Descriptive features $(\mathrm{N}=312)$ & & & $\mathbf{n}$ & $\begin{array}{c}\text { HPPQ } \\
\text { Mean } \pm \text { SD }\end{array}$ & $\begin{array}{c}\text { SQOL-F } \\
\text { Mean } \pm \text { SD }\end{array}$ \\
\hline Age* & $\begin{array}{l}18-24 \\
25-31 \\
32-38 \\
39 \text { and above }\end{array}$ & $\begin{array}{l}a \\
b \\
c \\
d\end{array}$ & $\begin{array}{c}70 \\
66 \\
157 \\
19\end{array}$ & $\begin{array}{l}90.20 \pm 7.01 \\
87.74 \pm 5.03 \\
88.14 \pm 5.29 \\
88.00 \pm 5.28\end{array}$ & $\begin{array}{l}63.96 \pm 5.51 \\
62.86 \pm 6.64 \\
64.11 \pm 6.02 \\
65.20 \pm 4.09\end{array}$ \\
\hline Test statistics & & & & 2.703 & 1.044 \\
\hline$p$-value & & & & 0.046 & 0.373 \\
\hline Significant difference & & & & $a>b, c, d$ & \\
\hline Education level* & $\begin{array}{l}\text { Primary education ar } \\
\text { Secondary education } \\
\text { University and above }\end{array}$ & $\mathrm{d}$ below & $\begin{array}{c}172 \\
106 \\
34\end{array}$ & $\begin{array}{l}87.11 \pm 5.10 \\
88.14 \pm 6.20 \\
87.91 \pm 4.93\end{array}$ & $\begin{array}{l}63.35 \pm 5.60 \\
64.31 \pm 6.57 \\
65.22 \pm 5.50\end{array}$ \\
\hline Test statistics & & & & 1.122 & 1.841 \\
\hline$p$-value & & & & 0.295 & 0.190 \\
\hline Place of residence* & $\begin{array}{l}\text { City } \\
\text { County } \\
\text { Village }\end{array}$ & & $\begin{array}{c}55 \\
164 \\
93\end{array}$ & $\begin{array}{l}87.21 \pm 5.56 \\
87.81 \pm 5.12 \\
87.27 \pm 6.02\end{array}$ & $\begin{array}{l}64.30 \pm 5.57 \\
63.81 \pm 5.75 \\
63.76 \pm 6.55\end{array}$ \\
\hline $\begin{array}{l}\text { Test statistics } \\
\text { p-value }\end{array}$ & & & & $\begin{array}{l}0.406 \\
0.667\end{array}$ & $\begin{array}{l}0.165 \\
0.848\end{array}$ \\
\hline Marital status ${ }^{\dagger}$ & $\begin{array}{l}\text { Married } \\
\text { Single }\end{array}$ & & $\begin{array}{c}292 \\
20\end{array}$ & $\begin{array}{l}87.55 \pm 5.42 \\
87.45 \pm 6.53 \\
\end{array}$ & $\begin{array}{l}75.46 \pm 5.47 \\
76.00 \pm 3.44\end{array}$ \\
\hline $\begin{array}{l}\text { Test statistics } \\
\text { p-value }\end{array}$ & & & & $\begin{array}{l}2.701 \\
0.932\end{array}$ & $\begin{array}{l}4.071 \\
0.665\end{array}$ \\
\hline Income level* & $\begin{array}{l}\text { High } \\
\text { Moderate } \\
\text { Low }\end{array}$ & & $\begin{array}{c}68 \\
176 \\
68\end{array}$ & $\begin{array}{l}88.01 \pm 5.56 \\
88.68 \pm 5.92 \\
88.55 \pm 5.54\end{array}$ & $\begin{array}{l}64.44 \pm 5.84 \\
63.68 \pm 5.97 \\
63.83 \pm 6.08\end{array}$ \\
\hline $\begin{array}{l}\text { Test statistics } \\
p \text {-value }\end{array}$ & & & & $\begin{array}{l}0.336 \\
0.715\end{array}$ & $\begin{array}{l}0.397 \\
0.363\end{array}$ \\
\hline Pregnancy type $^{\dagger}$ & $\begin{array}{l}\text { Planned pregnancy } \\
\text { Unplanned pregnan }\end{array}$ & & $\begin{array}{c}216 \\
96\end{array}$ & $\begin{array}{l}87.54 \pm 5.59 \\
87.56 \pm 5.28 \\
\end{array}$ & $\begin{array}{l}75.33 \pm 5.42 \\
75.86 \pm 5.22 \\
\end{array}$ \\
\hline $\begin{array}{l}\text { Test statistics } \\
p \text {-value }\end{array}$ & & & & $\begin{array}{l}0.022 \\
0.981\end{array}$ & $\begin{array}{l}1.659 \\
0.420\end{array}$ \\
\hline Month of gestation* & $\begin{array}{l}\text { 1, 2, } 3 \text { months } \\
4,5,6 \text { months } \\
7,8,9 \text { months }\end{array}$ & $\begin{array}{l}a \\
b \\
c\end{array}$ & $\begin{array}{c}48 \\
156 \\
108\end{array}$ & $\begin{array}{l}88.22 \pm 5.53 \\
87.22 \pm 5.50 \\
87.72 \pm 5.47\end{array}$ & $\begin{array}{l}73.68 \pm 4.89 \\
75.97 \pm 5.34 \\
75.61 \pm 5.46\end{array}$ \\
\hline Test statistics & & & & 0.693 & 3.426 \\
\hline$p$-value & & & & 0.501 & 0.034 \\
\hline Significant difference & & & & & $b, c>a$ \\
\hline Number of pregnancy* & $\begin{array}{l}1 \\
2 \\
3 \\
4 \text { and more }\end{array}$ & & $\begin{array}{l}105 \\
101 \\
82 \\
24 \\
\end{array}$ & $\begin{array}{l}88.51 \pm 5.87 \\
86.52 \pm 5.07 \\
87.43 \pm 5.46 \\
88.04 \pm 5.08 \\
\end{array}$ & $\begin{array}{l}63.70 \pm 5.92 \\
63.55 \pm 6.21 \\
64.21 \pm 6.16 \\
64.95 \pm 4.17\end{array}$ \\
\hline $\begin{array}{l}\text { Test statistics } \\
p \text {-value }\end{array}$ & & & & $\begin{array}{l}2.358 \\
0.072\end{array}$ & $\begin{array}{l}0.475 \\
0.700\end{array}$ \\
\hline Number of children* & $\begin{array}{l}\text { None } \\
1-2 \\
3-4\end{array}$ & & $\begin{array}{c}105 \\
183 \\
24\end{array}$ & $\begin{array}{l}88.51 \pm 5.87 \\
86.93 \pm 5.25 \\
88.04 \pm 5.08\end{array}$ & $\begin{array}{l}63.70 \pm 5.92 \\
63.84 \pm 6.18 \\
64.95 \pm 4.17\end{array}$ \\
\hline $\begin{array}{l}\text { Test statistics } \\
p \text {-value }\end{array}$ & & & & $\begin{array}{l}2.900 \\
0.057\end{array}$ & $\begin{array}{l}0.436 \\
0.647\end{array}$ \\
\hline Number of prenatal care* & $\begin{array}{l}\text { Less than } 4 \text { times } \\
4 \text { times } \\
\text { More than } 4 \text { times }\end{array}$ & $\begin{array}{l}a \\
b \\
c\end{array}$ & $\begin{array}{c}84 \\
57 \\
171\end{array}$ & $\begin{array}{l}88.81 \pm 5.03 \\
88.52 \pm 4.08 \\
91.54 \pm 6.20\end{array}$ & $\begin{array}{l}77.03 \pm 5.89 \\
76.24 \pm 5.94 \\
76.00 \pm 5.53 \\
\end{array}$ \\
\hline Test statistics & & & & 10.298 & 1.685 \\
\hline $\begin{array}{l}\mathrm{p} \text {-value } \\
\text { Significant difference }\end{array}$ & & & & $\begin{array}{l}0.000 \\
c>a, b\end{array}$ & 0.153 \\
\hline $\begin{array}{l}\text { The history of sexually } \\
\text { transmitted disease }{ }^{\dagger}\end{array}$ & $\begin{array}{l}\text { Evet } \\
\text { Hayır }\end{array}$ & & $\begin{array}{c}18 \\
294 \\
\end{array}$ & $\begin{array}{l}87.88 \pm 3.34 \\
88.55 \pm 5.87 \\
\end{array}$ & $\begin{array}{l}77.55 \pm 3.88 \\
75.37 \pm 5.42 \\
\end{array}$ \\
\hline Test statistics & & & & 5.045 & 1.988 \\
\hline$p$-value & & & & 0.637 & 0.093 \\
\hline
\end{tabular}

*One-way ANOVA, †Independent groups t-test. HPPQ: The Health Practices in Pregnancy Questionnaire; SQOL-F: The Sexual Quality of Life-Female Questionnaire. 
In the Table 3, HPPQ and SQOL-F scores were compared according to the descriptive features of the pregnant women. Accordingly, mean HPPQ scores of the pregnant women in the age group of 18-24 are higher than the other age groups in a statistically significant way. Also, mean HPPQ scores of the pregnant women who underwent prenatal care for more than 4 times are higher than the other groups in a statistically significant way. Mean SQOL-F scores of the pregnant women who are in the 2nd and 3rd trimesters are higher than those in the 1 st trimester which is statistically significant.

\section{Discussion}

In our study, the mean score of the Health Practices in Pregnancy Questionnaire (HPPQ) was $87.55 \pm 5.49$. The mean HPPQ score was $114.43 \pm 17.90$ in the study of Sis Çelik and Aksoy, ${ }^{[10]} 111.76 \pm 18.53$ in the study of Özcan and Kizılkaya Beji ${ }^{[1]]}$ and $112.64 \pm 13.87$ in the study of Çapik et al. ${ }^{[12]}$ The lowest score that a respondent can get is 33 while the highest score is 165 in HPPQ. Accordingly, the level of health practices of the pregnant women is low in our study.

We found in our study that the mean HPPQ scores of the pregnant women in the age group of 18-24 were higher than the other age groups. Similarly, Özcan and Kizilkaya Beji found in their study ${ }^{[1]}$ that the mean HPPQ scores of the pregnant women in the age group of 15-24 were higher than those of the pregnant women with advanced ages. In the study of Sis Çelik and Aksoy, ${ }^{[10]}$ the authors found that the mean HPPQ scores of the pregnant women in the age group of 25-34 were higher than those in the other age groups. They believed that young age group obtained information by looking up information about health practices in pregnancy.

Medical checks are the necessary practices from the beginning of pregnancy up to the labor for mother and newborn health. The indication of the sufficiency of prenatal care is the number of prenatal visits. ${ }^{[1,13]}$ In our study, the mean HPPQ scores of the pregnant women who underwent prenatal care for more than 4 times were higher than the mean scores of those who underwent prenatal care for 4 times or less. Sis Çelik and Aksoy $^{[10]}$ found in their study that the mean HPPQ scores of the pregnant women who underwent prenatal care for more than 4 times were significantly higher.

In our study, the mean SQOL-F score of the pregnant women was $63.88 \pm 5.95$. In their study, Kurıkkale ${ }^{[14]}$ found that the mean SQOL-F score of the pregnant women was $81.59 \pm 15.95$. We found that the mean SQOL-F scores reported in the study of Kirikkale and two other international studies were higher than the mean score of our study. ${ }^{[9,15]}$ Considering that the maximum score one can get in SQOL-F is 100, the score of the sexual quality of life of the pregnant women included in our study is $63.88 \pm 5.95$, which is a moderate level.

Hormonal, anatomical and physiological changes may appear as the factors affecting the sexual quality of life in pregnancy negatively. In accordance with these factors, sexual responses may change compared to the pregnancy period. ${ }^{[14]}$ Kodaz found in their study that the pregnant women had problems in their sexual lives due to the physical discomforts and physical changes in half of the cases, nausea and vomiting in nearly half of the cases, galactorrhea and tenderness in one third of the cases, religious or cultural thoughts in one seventh of the cases and negative reactions of the spouses of the pregnant women, and the frequency of sexual intercourse decreased during pregnancy and therefore their sexual quality of life was affected negatively. ${ }^{[16]}$ Similarly, Galazka et al. reported that the frequency of sexual intercourse and sexual activities decreased during pregnancy the lack of sexual drive increased, and that primiparous pregnant women experienced changes in sexual arousal, vaginal lubrication and orgasm especially in the third trimester. ${ }^{[17]}$ Another study reported sexual desire disorder in $88.9 \%$ of the pregnant women, sexual arousal disorder in $86.9 \%$ of them, vaginal dryness in $42.8 \%$ of them, orgasm disorder in $69.6 \%$ of them and sexual satisfaction disorder in $48 \%$ of them. ${ }^{[18]}$ In our study, we found that the mean SQOL-F scores of the pregnant women who were in the 1st trimester were significantly lower than the mean SQOL-F scores of the pregnant women who were in the $2 \mathrm{nd}$ and $3 \mathrm{rd}$ trimesters.

\section{Conclusion}

In our study, the level of health practices in pregnancy is low and the level of sexual quality of life is moderate. Also, the health practices of the pregnant women who are young and underwent prenatal care for more than 4 times are better. In terms the sexual quality of life, the scores of the pregnant women in the $2 \mathrm{nd}$ and $3 \mathrm{rd}$ trimesters are higher than the scores of those in the 1st trimester.

Conflicts of Interest: No conflicts declared. 


\section{References}

1. Kızılkaya Beji N, Dişsiz M. Gebelik ve hemşirelik yaklaşımı. In: Kızılkaya Beji N, editor. Kadın sağlı̆̆ı ve hastalıkları. 2nd ed. İstanbul: Nobel Tip Kitabevleri; 2016. p. 250-97.

2. Türkiye Ulusal Anne Ölümleri Çalışması. 2005 [Internet] Erişim: http://www.hips.hacettepe.edu.tr/uaop_ankara/ozet_ rapor.pdf

3. Lindgren $\mathrm{K}$. Testing the health practices in pregnancy questionnaire-II. J Obstet Gynecol Neonatal Nurs 2005;34:46572.

4. Gürkan ÖC. Gebelik döneminde cinsellik nasıl etkileniyor? Androloji Bülteni 2007;28:80-5.

5. Quilliam S. Sex during pregnancy: yes, yes, yes! J Fam Plann Reprod Health Care 2010;36:97-8.

6. Gibbs RS, Karlan BY, Haney AF, Nygaard I. Danforth's obstetrik ve jinekoloji (Ayhan A, Trsl.) 10th ed. Ankara: Güneş Tip Kitabevleri; 2010. p. 1-758.

7. Er S. Gebelikte sağlık uygulamaları ölçeği Türkçe formunun geçerlik ve güvenirlik çalışması. MSc thesis, Ege Üniversitesi Sağlık Bilimleri Enstitüsü, İzmir, 2006.

8. Symonds T, Boolell M, Quirk F. Development of questionnaire on sexual quality of life in women. J Sex Marital Ther 2005;31:385-97.

9. Tuğut N, Gölbaşı Z. Cinsel yaşam kalitesi ölçeği - Kadın Türkçe versiyonunun geçerlik ve güvenirlik çalışması. Cumhuriyet Tip Dergisi 2010;32:172-80.
10. Sis Çelik A, Aksoy DY. Gebelerin öz bakım gücü ile sağlık uygulamaları düzeylerinin ve etkileyen faktörlerin belirlenmesi. Gümüşhane Üniversitesi Sağlı Bilimleri Dergisi 2019;8: $111-9$.

11. Özcan H, Kizılkaya Beji N. Health practices of pregnant women in Gumushane City Center. Perinatal Journal 2015;23: $13-9$.

12. Çapık A, Sakar T, Ejder Apay S. Gebelikte să̆lık uygulamalar1 ile duygusal zeka arasındaki ilişki. Uluslararası Hakemli Hemşirelik Araştırmaları Dergisi 2016;6:75-88.

13. Turan T, Ceylan S, Teyikçi S. Annelerin düzenli prenetal bakım alma durumları ve etkileyen faktörler. Fırat Sağlı Hizmetleri Dergisi 2008;3:157-73.

14. Kırıkkaleli Z. Gebelerin cinsel yaşam kalitesi ve etkileyen faktörler. MSc thesis, Yakın Doğu Üniversitesi Sağlık Bilimleri Enstitüsü, Lefkoşa, KKTC, 2015.

15. Maasoumi R, Lamyian M, Montazeri A, Azin SA, AguilarVafaie ME, Hajizadeh E. The sexual quality of life-female (SQOL-F) questionnaire: translation and psychometric properties of the Iranian version. Reprod Health 2013;10:1-6.

16. Kodaz ND. Gebelikte cinsel yaşam kalitesi ve ilişkili faktörler. MSc thesis, Selçuk Üniversitesi Sağlık Bilimleri Enstitüsü, Konya, 2013.

17. Galazka I, Drosdzol-Cop A, Naworska B, Czajkowska M, Skrzypulec-Plinta V. Changes in the sexual function during pregnancy. J Sex Med 2015;12:445-54.

18. Tosun Güleroğlu F, Gördeles Beşer N. Evaluation of sexual functions of the pregnant women. J Sex Med 2014;11:146-53.

Bu makalenin kullanım izni Creative Commons Attribution-NoCommercial-NoDerivs 3.0 Unported (CC BY-NC-ND3.0) lisansı aracılığıyla bedelsiz sunulmaktadir. / This work is licensed under the Creative Commons Attribution-NonCommercial-NoDerivs 3.0 Unported (CC BY-NC-ND3.0) License. To view a copy of this license, visit http://creativecommons.org/licenses/by-nc-nd/3.0/ or send a letter to Creative Commons, PO Box 1866, Mountain View, CA 94042, USA. 